\title{
PENGARUH KEBISINGAN LALU LINTAS TERHADAP KETERGANGGUAN PEGAWAI KANTOR BKD PROVINSI SULAWESI TENGGARA
}

\author{
M Basri1), Irwan Lakawa ${ }^{2}$, Sulaiman ${ }^{3)}$, \\ ${ }^{1}$ Mahasiswa Program Studi Teknik Sipil, Fakultas Teknik, Universitas Sulawesi Tenggara \\ email: muh.basri919@gmail.com \\ ${ }^{2}$ Dosen Program Studi Teknik Sipil, Fakultas Teknik, Universitas Sulawesi Tenggara \\ email: ironelakawa@gmail.com \\ ${ }^{3}$ Dosen Program Studi Teknik Sipil, Fakultas Teknik, Universitas Sulawesi Tenggara
}

\begin{abstract}
Noise is unwanted sound, which can impair the health and comfort of the environment, have a source and propagates through a medium. Provincial Civil Service Agency of Southeast Sulawesi's Office is located at the intersection of Drs. H. Abdullah Silondae Street, Laute Street and Malik Raya street with dense vehicle traffic, which Drs. H. Abdulah Silondae Street is the route of public transportation to the downtown to UHO Campus. The purpose of this research is to analyze the noise level due to the activities of the traffic in the area of Provincial Civil Service Agency of Southeast Sulawesi's Office, analyzing the annoyance perception employees due to the traffic noise and the characteristics of respondents, and analyze the influence of noise level against the employees annoyance level. Data analysis of obtained that the average noise level in the area of Provincial Civil Service Agency of Southeast Sulawesi's Office has passed the quality standards of noise to the office area. The perception of employees due to interference noise is $44 \%$ of the respondents who stated not bothered by noise in the area, $24 \%$ of respondents who stated a bit distracted, $24 \%$ stated quite disturbed, and $8 \%$ declared disturbed. As for the noise have significant influence towards employees level of annoyance.
\end{abstract}

Keywords: Noise, Traffic, Office

\begin{abstract}
ABSTRAK
Kebisingan adalah bunyi yang tidak diinginkan, yang dapat mengganggu kesehatan dan kenyamanan lingkungan, mempunyai sumber dan menjalar melalui media perantara. Kantor Badan Kepegawaian Daerah Provinsi Sulawesi Tenggara di Kota Kendari terletak pada simpang empat Jalan Drs. H. Abdullah Silondae, Jalan Laute, dan Jalan Malik Raya yang sarat akan lalu lintas kendaraan, dimana salah satu jalannya yaitu Jalan Drs. $H$. Abdulah Silondae merupakan jalan poros Kampus UHO ke Kota yang mana mobil angkutan melalui jalan tersebut.Tujuan penelitian ini adalah untuk menganalisis tingkat kebisingan akibat aktifitas lalu lintas di kawasan Kantor Badan Kepegawaian Daerah Provinsi Sulawesi Tenggara, menganalisis persepsi ketergangguan pegawai akibat kebisingan lalu lintas dan karakteristik responden, serta menganalisis pengaruh tingkat kebisingan terhadap tingkat ketergangguan pegawai.Dari hasil analisis data pengukuran kebisingan diperoleh bahwa tingkat kebisingan rata-rata di kawasan Kantor Badan Kepegawaian Daerah Provinsi Sulawesi Tenggara telah melewati standar baku mutu kebisingan untuk kawasan perkantoran. Persepsi pegawai akibat gangguan kebisingan adalah 44\% responden yang menyatakan tidak terganggu dengan kebisingan di kawasan tersebut, $24 \%$ responden yang menyatakan agak terganggu, 24\% menyatakan cukup terganggu, dan $8 \%$ menyatakan terganggu. Adapun kebisingan memiliki pengaruh yang signifikan terhadap tingkat ketergangguan pegawai $B K D$.
\end{abstract}

Kata Kunci: Kebisingan, Ketergangguan, Sekolah

\section{PENDAHULUAN}

\section{Latar Belakang}

Lalu lintas jalan merupakan sumber utama kebisingan yang mengganggu sebagian besar masyarakat. Bunyi yang ditimbulkan oleh lalu lintas adalah bunyi yang tidak konstan tingkat suaranya (Setiawan, 2001). Kebisingaan akibat kendaraan bermotor, berbanding lurus dengan jumlah dan kecepatan kendaraan bermotor yang melewati jalan, semakin banyak dan cepat kendaraan bermotor, maka dengan sendirinya kebisingan jalan raya akan semakin meningkat (Martono, 2008). 
Dua jenis ketergangguan utama yang sering dikeluhkan akibat intervensi bising jalan raya terhadap kegiatan tertentu adalah gangguan istirahat seperti kesulitan tidur dan berubahnya pola tidur serta gangguan komunikasi/percakapan yang umumnya menjadi masalah serius pada sekolah, rumah, dan tempat kerja (Banerjee, 2008).

Kebisingan yang berlebihan juga dapat mengakibatkan masalah-masalah mental dan kesehatan fisik. Penelitian telah menunjukkan bahwa orang-orang yang tinggal di dekat jalanjalan dan lalu lintas yang sibuk atau dekat dengan bandara, menghabiskan waktu lebih sedikit di halaman mereka, dan memiliki jumlah tamu lebih sedikit dari orang-orang yang tinggal di daerah lebih tenang (Bluhm, 2004).

Masalah kebisingan yang diakibatkan oleh kegiatan transportasi pada umumnya kurang diperhatikan oleh penduduk yang menetap di daerah tersebut, dampak dari kebisingan lingkungan yang terus-menerus akan mengakibatkan gangguan pendengaran, gangguan fisiologi, dan gangguan pada pembicaraan.

Peneliti biasanya memprediksi kebisingan lalu lintas dengan menggunakan 3 metode yaitu dengan membuat peta kebisingan, pemodelan kebisingan, dan pengukuran kebisingan. Bukti yang ada menunjukkan bahwa kebisingan lalu lintas adalah sumber utama ketergangguan lingkungan; peneliti menemukan korelasi positif antara tingkat kebisingan dan tingkat ketergangguan (Li dkk, 2008).

Kantor Badan Kepegawaian Daerah Provinsi Sulawesi Tenggara di Kota Kendari terletak pada simpang empat Jalan Drs. H. Abdullah Silondae, Jalan Laute, dan Jalan Malik Raya dilalui kendaraan. Menurut hasil penelitian Lakawa (2016) menyatakan bahwa tingkat kebisingan rata-rata pada jalan raya di kota Kendari adalah 75,5 dB untuk jalan arteri dan 73,4 dB untuk jalan kolektor. Kantor Badan Kepegawaian Daerah Provinsi Sulawesi Tenggara berada pada jarak yang relatif dekat terhadap sumber kebisingan di Jalan Drs. H. Abdulah Silondae. Selain itu kurangnya vegetasi/tanaman di kawasan Kantor Badan Kepegawaian Daerah Provinsi Sulawesi Tenggara sebagai noise barrier juga menjadi bahan pertimbangan peneliti untuk memilih lokasi penelitian di Kantor Badan Kepegawaian Daerah Provinsi Sulawesi Tenggara.

\section{Rumusan Masalah}

Adapun rumusan masalah pada penelitian ini adalah :

1) Seberapa besar tingkat kebisingan akibat lalu lintas di kawasan kantor Badan Kepegawaian Daerah Provinsi Sulawesi Tenggara?

2) Bagaimana persepsi ketergangguan pegawai akibat kebisingan?

3) Bagaimana pengaruh tingkat kebisingan terhadap ketergangguan pegawai?

\section{Tujuan Penelitian}

Adapun tujuan penelitian adalah :

1) Menganalisis tingkat kebisingan akibat lalu lintas di kawasan kantor Badan Kepegawaian Daerah Provinsi Sulawesi Tenggara.

2) Menganalisis persepsi ketergangguan pegawai akibat kebisingan

3) Menganalisis pengaruh tingkat kebisingan terhadap ketergangguan pegawai.

\section{TINJAUAN PUSTAKA}

\section{Kebisingan}

Kebisingan adalah suara yang tidak dikehendaki dan menggangu manusia.Berdasarkan SK Menteri Negara Lingkungan Hidup No. Kep.Men48/MENLH/11/1996, kebisingan adalah bunyi yang tidak diinginkan dari suatu usaha atau kegiatan dalam tingkat dan waktu tertentu yang dapat menimbulkan gangguan kesehatan manusia dan kenyamanan lingkungan, termasuk ternak, satwa, dan sistem alam. Menurut Menteri Kesehatan Republik Indonesia bahwa bising adalah semua suara yang tidak dikehendaki yang bersumber dari alat-alat produksi dan atau alatalat kerja yang pada tingkat tetentu dapat menimbulkan gangguan pendengaran.

Kebisingan dapat dibagi menjadi beberapa kategori, yaitu (Wardhana, W.A, 1999, dalam Leonard, 2014):

a. Berdasarkan frekuensi, tingkat tekanan bunyi, tingkat bunyi, dan tenaga bunyi maka bising dapat dibagi dalam 3 kategori:

1) Kebisingan impulsif, yaitu kebisingan yang datangnya tidak secara terus menerus, akan tetapi sepotong-sepotong. Contohnya: kebisingan yang datang dari suara palu yang dipukulkan, kebisingan 
yang datang dari mesin pemancang tiang pancang.

2) Kebisingan kontinyu, yaitu kebisingan yang datang secara terus-menerus dalam waktu yang cukup lama. Contohnya: kebisingan yang datang dari suara mesin yang dijalankan (dihidupkan).

3) Kebisingan semi kontinyu (intermittent), yaitu kebisingan kontinyu yang hanya sekejap, kemudian hilang dan mungkin akan datang lagi. Contohnya: suara mobil atau pesawat terbang yang sedang lewat.

b. Berdasarkan waktu terjadinya, maka bising dibagi dalam beberapa jenis:

1) Bising kontinyu dengan spectrum luas, misalnya bising karena mesin, kipas angin. Spectrum sempit, misalnya: bunyi gergaji. Bising terputus-putus atau intermitten misalnya: lalu lintas, bunyi pesawat terbang di udara.

2) Bising sehari penuh (full time noise) dan bising setengah hari (part time noise).

3) Bising terus menerus (steady noise) dan bising impulsive (impuls noise) ataupun bising sesaat (letupan).

c. Berdasarkan skala intensitas, maka tingkat kebisingan sangat tenang, tenang, sedang, kuat, sangat hiruk pikuk, dan menulikan.

1) Menulikan, $100 \mathrm{~dB}-120 \mathrm{~dB}$, contohnya: halilintar, meriam, mesin uap.

2) Sangat hiruk pikuk, $80 \mathrm{~dB}-100 \mathrm{~dB}$, contohnya: jalan hiruk pikuk, pabrik, peluit.

3) Kuat, $60 \mathrm{~dB}-80 \mathrm{~dB}$, contohnya: kantor gaduh, jalanan, radio, gedung perusahaan.

4) Sedang, $40 \mathrm{~dB}-60 \mathrm{~dB}$, contohnya: rumah gaduh, kantor, percakapan kuat (ribut), radio perlahan.

5) Tenang, $20 \mathrm{~dB}-40 \mathrm{~dB}$, contohnya: rumah tenang, kantor perorangan, auditorium, percakapan.

6) Sangat tenang, $0 \mathrm{~dB}-20 \mathrm{~dB}$, contohnya: bunyi daun, berbisik.

\section{Efek Kebisingan}

Efek dari kebisingan menurut KEP48/MENLH/11/1996 dibagi menjadi dua yaitu :

1. Akibat - akibat badaniah (kehilangan pendengaran dan akibat - akibat fisiologis)

a) Kehilangan Pendengaran
Perubahan ambang batas sementara akibat kebisingan.

b) Akibat Fisiologis

Perubahan ambang batas permanen akibat kebisingan dan rasa tidak nyaman atau stres meningkat, tekanan darah meningkat, sakit kepala, bunyi dering.

2. Akibat - akibat Psikologis (gangguan emosional, gangguan gaya hidup, gangguan pendengaran)

a) Gangguan Emosional Kejengkelan, Kebingungan

b) Gangguan Gaya Hidup Gangguan tidur atau istirahat, hilang konsentrasi waktu bekerja, membaca, dsb,

c) Gangguan Pendengaran

Merintangi kemampuan mendengarkan $\mathrm{TV}$, radio, percakapan, telepon, dan sebagainya.

\section{Baku Mutu Tingkat Kebisingan}

$\begin{array}{rccr}\text { Menurut } & \text { Keputusan } & \text { Menteri } & \text { Negara } \\ \text { Lingkungan } & \text { Hidup } & \text { Nomor: } & \text { KEP- }\end{array}$
48/MENLH/11/1996 tentang Baku Tingkat Kebisingan, baku tingkat kebisingan adalah batas maksimal tingkat kebisingan yang diperbolehkan dibuang ke lingkungan dari usaha atau kegiatan sehingga tidak menimbulkan gangguan kesehatan manusia dan kenyamanan lingkungan.

Tabel 1. Baku Tingkat Kebisingan

\begin{tabular}{|c|c|}
\hline Peruntukan Kawasan & Tingkat kebisingan (dBA) \\
\hline Perumahan dan pemukiman & 55 \\
\hline Perdagangan dan jasa & 70 \\
\hline Perkantoran dan perdagangan & 65 \\
\hline Ruang hijau terbuka & 50 \\
\hline Industri & 70 \\
\hline Pemerintah dan fasilitas umum & 60 \\
\hline Rekreasi & 70 \\
\hline Pelabuhan & 70 \\
\hline Rumah sakit atau sejenisnya & 55 \\
\hline Sekolah atau sejenisnya & 55 \\
\hline Tempat ibadah atau sejenisnya & 55 \\
\hline
\end{tabular}

(Sumber: Menteri Lingkungan Hidup, 1996)

\section{Zona Kebisingan}

Daerah dibagi sesuai dengan titik kebisingan yang diizinkan (Sastrowinoto, 1985, dalam Leonard 2014) :

Zona A : Intensitas $35-45 \mathrm{~dB}$. Zona yang diperuntukkan bagi tempat penelitian, RS, tempat perawatan kesehatan/sosial \& sejenisnya. 
Zona B : Intensitas 45 - $55 \mathrm{~dB}$. Zona yang diperuntukkan bagi perumahan, tempat pendidikan dan rekreasi.

Zona $\mathrm{C}$ : Intensitas $50-60 \mathrm{~dB}$. Zona yang diperuntukkan bagi perkantoran, perdagangan dan pasar.

Zona D : Intensitas $60-70 \mathrm{~dB}$. Zona yang diperuntukkan bagi industri, pabrik, stasiun KA, terminal bis dan sejenisnya.

Berdasarkan PP No. 55 tahun 2012 kendaraan sebagaimana di maksud dalam Pasal 69, Suara klakson sebagaimana dimaksud dalam Pasal 64 ayat (2) huruf $\mathrm{f}$ paling rendah 83 desibel atau $\mathrm{dB}(\mathrm{A})$ dan paling tinggi 118 desibel.

\section{Pengukuran Kebisingan}

Perhitungan tingkat kebisingan langsung dengan menggunakan SLM yang kemudian diolah sesuai sehingga mendapatkan nilai Leq yaitu nilai tingkat kebisingan ekuivalen. Pengolahan data kebisingan yang diperoleh SLM dilakukan dengan distribusi non sampling (Huboyo dan Sumiyati 2008, dalam Fadilah 2016). Distribusi mean sampling yang terdistribusi normal untuk nilai $\mathrm{n}$ berapapun (tidak tergantung ukuran sampel). Sementara itu dari suatu populasi yang tidak terdistribusi normal, tapi jika ukuran sampel cukup besar ( $\mathrm{n}$ > 30), distribusi mean sampling akan mendekati suatu distribusi normal (Gaussian) apapun bentuk asli distribusi populasinya. Pernyataan ini dikenal dengan teorema limit pusat (central limit theorem) (Harinaldi, 2005 dalam Fadilah 2016 ).

Pada penelitian ini perhitungan kebisingan dapat dianalisis dengan distribusi frekuensi. Adapun komponen pada distribusi frekuensi yaitu : (Huboyo 2008, dalam Fadilah 2016)

1. Range

Range (r) adalah jangkauan data yang diperoleh untuk membatasi data - data yang akan diolah. Adapun rumus range adalah sebagai berikut :

$\mathrm{r}=\max -\min$

Keterangan :

$\mathrm{r} \quad=$ range

$\max =$ data maksimum

$\min =$ data minimum

2. Interval Kelas

Interval kelas adalah interval yang diberikan untuk menetapkan kelas kelas dalam distribusi, Banyaknya interval kelas dapat di analisis dengan menggunakan persamaan (2).

$i=\frac{r}{k}$

Keterangan :

$\mathrm{i}=$ interval kelas

$\mathrm{k}=$ kelas

3. Kelas

Menentukan banyaknya jumlah kelas dalam suatu distribusi data dapat ditentukan dengan menggunakan persamaan (3).

$\mathrm{k}=1+3,3 \log (\mathrm{n})$

Keterangan :

$\mathrm{k}=$ kelas

$\mathrm{n}=$ banyaknya data

4. Nilai Tengah Kelas

Nilai tengah kelas adalah nilai yang terdapat di tengah interval kelas. Nilai tengah dapat dianalisis dengan menggunakan persamaan (4)

$N T K=\frac{B A}{B B}$

Keterangan :

$\mathrm{BA}=$ Batas atas

$\mathrm{BB}=$ Batas bawah

5. Frekuensi

Dalam statistik, "frekuensi" mengandung pengertian : angka (bilangan) yang menunjukkan seberapa kali suatu variable (yang diambangkan dengan angka-angka itu) berulang dalam deretan angka tersebut; atau berapa kalikah suatu variable (yang dilambangkan dengan angka itu) muncul dalam deretan angka tersebut.

6. Tingkat kebisingan dalam angka petunjuk Pengukuran dengan sistem angka penunjuk yang paling banyak digunakan adalah angka penunjuk ekuivalen (equivalent index (Leq). Angka penunjuk ekuivalen (Leq) adalah tingkat kebisingan yang berubah ubah (fluktuatif) yang diukur selama waktu tertentu, yang besarnya setara dengan tingkat kebisingan tunak (steady) yang diukur pada selang waktu yang sama. Sistem angka penunjuk yang dipakai adalah angka penunjuk presentase. Sistem pengukuran ini menghasilkan angka tunggal yang menunjukkan presentase tertentu dari tingkat kebisingan yang muncul selama waktu tersebut. Presentase yang mewakili tingkat kebisingan minoritas adalah kebisingan yang muncul $10 \%$ dari keseluruhan data $(L 90)$ dan tingkat kebisingan mayoritas yang muncul 99\% dari data pengukuran (L1). Presentase tengah ( $L 50)$ umumnya identik dengan kebisingan rata-rata selama periode 
pengukuran. $L 90$ disebut kebisingan buangan atau sisa $L 1$ adalah tingkat kebisingan yang umumnya menimbulkan gangguan. Khusus untuk dijalan raya, $L 90$ akan menunjukkan tingkat kebisingan latar belakang dari $L 1$ menunjukkan perkiraan tingkat kebisingan maksimum. Sehingga $L 1$ adalah sistem pengukuran angka penunjuk yang harus benar benar diperhatikan.L1 dan Leq dijadikan acuan untuk dibandingkan dengan bakuan yang berlaku, sementara $L 90$ dapat diabaikan karena umumnya selisih jauh dengan bakuan.

\section{Perhitungan Kebisingan}

Perhitungan angka penunjuk presentase manual dilakukan dengan membuat histogram seperti pada Gambar 1 dan Gambar 2 dengan mengambil contoh bahwa selama pengukuran diperoleh 120 buah data. Setelah diurutkan dan dihitung jumlah masing-masing tingkat kebisingan yang muncul, maka terbentuk batang-batang histogram. Bila diteliti kembali, maka keseluruhan luas area dibawah histogram adalah:

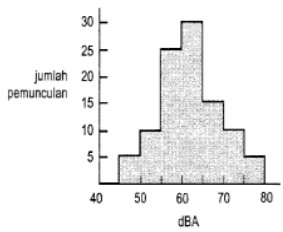

Gambar 1. Contoh histogram untuk pengukuran kebisingan dengan SLM

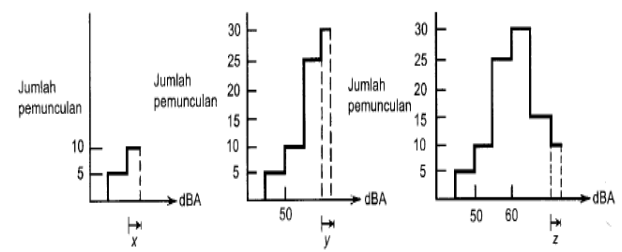

Gambar 2. Contoh potongan histogram untuk pengukuran L90, L50, dan L10

Dengan menggunakan SLM sederhana yang menyebabkan pemakai harus menghitung secara manual angka penunjuk presentasenya, tentu tidak mudah untuk menghitung angka penunjuk ekuivalennya. Namun demikian untuk kebisingan dari kendaraan bermotor, angka penunjuk ekuivalennya dapat dihitung menggunakan persamaan :

$\mathrm{Leq}=\mathrm{L}_{50}-0,43\left(\mathrm{~L}_{1}-\mathrm{L}_{50}\right) \ldots \ldots \ldots$ (5)

Keterangan:

Leq = tingkat bising sinambung equivalen dalam $\mathrm{dB}(\mathrm{A})$

$\mathrm{L}_{50}=$ angka petunjuk kebisingan $50 \%$

$\mathrm{L}_{1}=$ angka petunjuk kebisingan $1 \%$

Untuk memperediksi tingkat kebisingan pada jarak tertentu menggunakan persamaan berikut : (Setyawan, Zakki dan Iqbal (2015):

$$
\begin{aligned}
L 2= & \left.L 1-10 \log \left(\frac{r 2}{r 1}\right) d B A \ldots \ldots . .6\right) \\
& \text { Keterangan: } \\
\mathrm{L} 2= & \text { tingkat bising pada jarak } \mathrm{r} 2 \text { dari } \\
& \text { sumber }(\mathrm{dBA}) \\
\mathrm{L} 1= & \text { tingkat bising pada jarak r1 dari } \\
& \text { sumber }(\mathrm{dBA})
\end{aligned}
$$

\section{Analisa Korelasi}

Korelasi adalah pengukur hubungan dua variabel atau lebih yang dinyatakan dengan derajat keeratan atau tingkat hubungan antar variabel-variabel. Mengukur derajat hubungan dengan metode korelasi yaitu dengan koefisien korelasi r. Dalam hal ini, dengan tegas dinyatakan bahwa dalam analisis korelasi tidak mempersoalkan apakah variabel yang satu tergantung pada variabel yang lain atau sebaliknya. Jadi metode korelasi dapat dipakai untuk mengukur derajat hubungan antar variabel bebas dengan variabel bebas yang lainnya atau antar dua variable (Wardika, dkk, 2012). Dimana $r$ bervariasi antara 0 dan 1 , untuk perkiraan yang sempurna nilai $r=1$ apabila $r=0$ perkiraan suatu fungsi sangat jelek.

Menurut Sugiyono (2010), korelasi Rank Spearman digunakan untuk mencari hubungan atau untuk menguji signifikansi hipotesis asosiatif bila masing-masing variabel yang dihubungkan berbentuk ordinal, dan sumber data antar variabel tidak harus sama. Berikut ini merupakan rumus korelasi Rank Spearman

$$
\rho=1-\frac{6 \sum b_{i}^{2}}{n\left(n^{2}-1\right.}
$$

Keterangan:

$\rho=$ koefisien korelasi spearman rank

$b i=$ selisih peringkat setiap data

$\mathrm{n}=$ jumlah data

Berikut adalah pedoman untuk memberikan interpretasi serta analisis bagi koefisien korelasi: Tabel 2. Pedoman Interpretasi Koefisien Korelasi

\begin{tabular}{|l|l|}
\hline Interval Koefisien & Tingkat Hubungan \\
\hline $0,00-0,199$ & Sangat Rendah \\
\hline $0,20-0,399$ & Rendah \\
\hline $0,40-0,599$ & Sedang \\
\hline
\end{tabular}




\begin{tabular}{|l|l|}
\hline $0,60-0,799$ & Kuat \\
\hline $0,80-1,000$ & Sangat Kuat \\
\hline
\end{tabular}

Sumber: Sugiyono (2010)

\section{Uji Chi Square}

Uji chi square/kai kuadrat adalah sebuah metode statistika nonparametrik yang paling terkenal dan banyak digunakan. Uji ini tidak dibatasi oleh asumsi-asumsi ketat tentang jenis populasi maupun parameter populasi, yang dibutuhkan hanya derajat bebas. Uji kai kuadrat menggunakan teknik goodness of fit, yaitu dapat digunakan untuk menguji apakah terdapat perbedaan yang nyata antara banyak yang diamati yang masuk dalam masing-masing kategori dengan banyak yang diharapkan berdasarkan hipotesis nol. (Suciptawati, 2010). Uji chi square atau tes kai kuadrat tergolong ke dalam jenis statistik nonparametrik sehingga uji chi square tidak memerlukan syarat data berdistribusi normal (Sufren dan Natanael, 2013). Berikut ini adalah rumus dasar Chi Square (Sugiyono dalam Maulidya, 2011).

$$
\mathrm{X}^{2}=\frac{\sum\left(\mathrm{f}_{\mathrm{o}}-\mathrm{f}_{\mathrm{e}}\right)^{2}}{\mathrm{f}_{\mathrm{e}}} \quad \ldots \ldots \ldots \ldots \ldots
$$

\section{Keterangan:}

$\mathrm{X} 2$ = nilai chi square

fo $=$ frekuensi yang diobservasi

$\mathrm{fc}=$ frekuensi yang diharapkan

\section{Regresi}

Regresi adalah pengukur hubungan dua variabel atau lebih yang dinyatakan dengan bentuk hubungan atau fungsi. Untuk menentukan bentuk hubungan (regresi) diperlukan pemisahan yang tegas antara variabel bebas yang sering diberi simbol $\mathrm{X}$ dan variabel tak bebas dengan simbol Y. Pada regresi harus ada variabel yang ditentukan dan variabel yang menentukan atau dengan kata lain adanya ketergantungan variabel yang satu dengan variabel yang lainnya dan sebaliknya. Kedua variabel biasanya bersifat kausal atau mempunyai hubungan sebab akibat yaitu saling berpengaruh. Sehingga dengan demikian, regresi merupakan bentuk fungsi tertentu antara variabel tak bebas y dengan variabel bebas $\mathrm{X}$ atau dapat dinyatakan bahwa regresi adalah sebagai suatu fungsi $y=\mathrm{f}(\mathrm{x})$
Menurut Sugiono (2010) variabel yang akan diramalkan harus dituliskan pada ruas kiri persamaan dan disebut variabel tidak bebas (Y), sedangkan variabel yang nilainya dipergunakan untuk meramalkan variabel disebut variabel bebas (X). Untuk membuat peramalan Y dengan menggunakan nilai $\mathrm{X}$, maka $\mathrm{X}$ dan $\mathrm{Y}$ harus memiliki hubungan yang kuat. Kuat atau tidaknya hubungan $\mathrm{X}$ dan $\mathrm{Y}$ diukur dengan suatu nilai, yang disebut koefisien korelasi, sedangkan besamya pengaruh $\mathrm{X}$ terhadap $\mathrm{Y}$ adalah koefisien regresi.

Jenis-jenis regresi

1) Regresi linier

$\mathrm{Y}=\mathrm{a}+\mathrm{bX}$

2) Regresi non linier

a) Eksponensial:

$\mathrm{Y}=\mathrm{a} \mathrm{e}^{\mathrm{bX}}$

b) Logaritmik:

$\mathrm{Y}=\mathrm{a}+\mathrm{b} \log \mathrm{X}$

c) Pangkat/Power:

$\mathrm{Y}=\mathrm{aX}$

Keterangan:

$\mathrm{X}=$ variabel bebas (independent variable)

$\mathrm{Y}=$ variabel terikat (dependent variable)

$\mathrm{a}=$ penduga bagi intersep

$\mathrm{b}=$ penduga bagi koefisien regresi

\section{METODE PENELITIAN}

\section{Lokasi Penelitian}

Lokasi penelitian ini terletak di Jalan Drs. H. Abdullah Silondae, Kecamatan Mandonga, Kelurahan Mandonga, Kota Kendari Sulawesi Tenggara. Berikut ditampilkan lokasi penelitian berdasarkan google map.

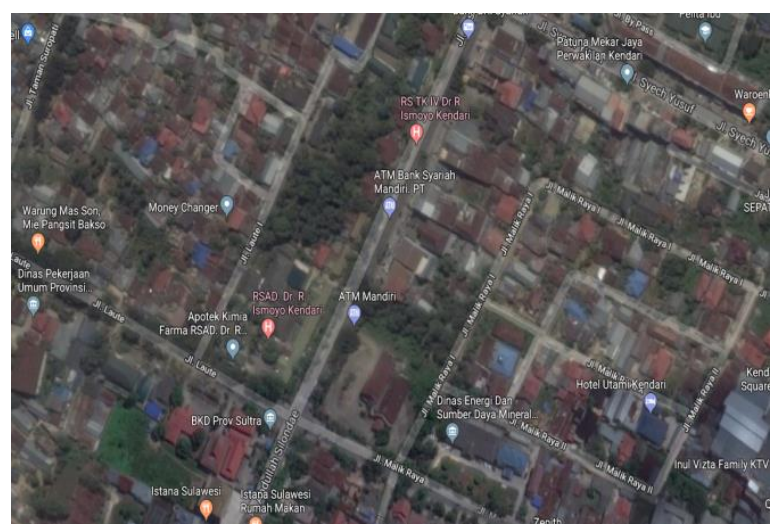


Gambar 3. Peta Lokasi Penelitian Sumber: Google Map

\section{Waktu Penelitian}

Penelitian dilaksanakan pada hari Senin 27 November 2017 dan Kamis, 30 November 2017 untuk data kebisingan selama 12 jam dan hari pada Selasa, 12 Desember 2017 untuk pengumpulan data kuisioner

\section{Populasi dan Sampel}

Populasi dalam penelitian ini adalah seluruh pegawai Badan Kepegawaian Daerah Provinsi Sulawesi Tenggara yang berjumlah 115 orang. Dikarenakan jumlah populasi yang relatif kecil serta terbatasnya jumlah pegawai yang bersedia diwawancarai sehingga jumlah sampel yang diperoleh pada penelitian ini adalah sebanyak 50 orang.

\section{Variabel Penelitian}

Adapun variabel dalam penelitian ini adalah tingkat kebisingan lalu lintas sebagai variabel bebas dan tingkat ketergangguan pegawai sebagai variabel terikat.

\section{Teknik Pengumpulan Data}

a) Data Kebisingan

Pengumpulan data ini dimaksudkan untuk mengetahui tingkat kebisingan kendaraan yang melintas di Jalan Drs. H. Abdullah Silondae yang diukur menggunakan Sound Level Meter selama 10 menit untuk memperoleh nilai Leq yang dimulai dari pukul 06.00 hingga pukul 18.00 WITA pada hari Senin 27 November 2017 dan Kamis, 30 November 2017.

b) Data Kuisioner

Pengumpulan data ini dimaksudkan untuk mengetahui respon pegawai terhadap kebisingan yang diakibatkan oleh kendaraan yang melintas di Jalan Drs. H. Abdullah Silondae yang meliputi karakteristik responden, dan pesepsi ketergangguan individu. Adapun metode pemilihan responden dilakukan secara incidental yaitu dengan berkunjung langsung ke responden yang bersedia untuk di wawancarai.

\section{Analisis Data Kebisingan}

Metode yang digunakan menganalisis data pengukuran kebisingan disesuaikan dengan rumusan penelitian pertama menggunakan metode matematis dengan langkah-langkah sebagai berikut:

a) Data pengukuran kebisingan dikumpulkan kemudian diperiksa terlebih dahulu untuk memastikan tidak ada data yang kosong/kurang.

b) Menginput data pengukuran kebisingan ke program Microsoft Excel untuk memudahkan proses penghitungan.

c) Data kemudian dianalisis dalam setiap satu interval pengukuran (10 menit) untuk mendapatkan nilai Leq.

d) Menentukan jumlah kelas dari data pengukuran dalam satu interval pengukuran menggunakan persamaan 3 .

e) Menghitung interval kelas menggunakan persamaan 2.

f) Menghitung titik tengah menggunakan persamaan 4.

g) Setelah menentukan banyaknya interval kelas, interval kelas, dan titik tengah, kemudian membuat tabel distribusi berdasarkan data pengukuran.

h) Membuat histogram dari data pengukuran dengan bantuan program Microsoft Excel.

i) Menghitung luas area dalam histogram dengan menggunakan rumus luas persegi panjang $(P \times L)$ dengan jumlah permunculan data sebagai panjang persegi $(P)$ dan interval data sebagai lebar persegi $(L)$.

j) Menghitung Leq menggunakan persamaan 6.

k) Demikian seterusnya hingga didapatkan nilai Leq untuk setiap interval waktu pengukuran kebisingan.

1) Data Leq kemudian dibandingkan dengan nilai ambang batas pada tabel 1. sesuai dengan peruntukkan kawasan perkantoran dan digrafikkan menggunakan program Microsoft Excel.

\section{Analisis Data Angket/Kuisioner}

Teknik analisis data yang digunakan pada penelitian ini disesuaikan dengan rumusan penelitian kedua dan ketiga dengan metode statistik non parametrik dan regresi dengan langkah-langkah sebagai berikut: 
a) Menginput data kuisioner ke program Microsoft Excel.

b) Data kuisioner yang masih berupa skala numerik dikonversikan ke 5 skala likert.

c) Prediksi tingkat kebisingan pada ruang kantor menggunakan persamaan 6 .

d) Membuat diagram hasil kuisioner.

e) Menginput data kusioner ke program SPSS yang meliputi variabel jenis kelamin (x1), usia (x2), tingkat pendidikan terakhir (x3), tingkat pendapatan perbulan (x4), masa kerja (x5), status kepegawaian (x6), tingkat ketergangguan individu (y), dan prediksi kebisingan pada ruangan kantor (Leq).

f) Melakukan uji chi square antara karakteristik responden dan tingkat ketergangguan.

g) Melakukan uji korelasi menggunakan metode Spearman Rank.

h) Menginterpretasikan hasil uji korelasi Spearman Rank berdasarkarkan tabel 2.

i) Melakukan uji regresi dengan tingkat ketergangguan individu (y) sebagai variabel terikat dan prediksi kebisingan pada ruangan kantor (Leq) sebagai variabel bebas menggunakan Microsoft Excel.

\section{Konsep Operasional}

Konsep operasional dalam penelitian ini dijelaskan dalam bagan alir berikut ini:

\section{Gambar 4. Bagan Alir Penelitian}

\section{HASIL DAN PEMBAHASAN \\ Deskripsi Umum Wilayah Penelitian}

Badan Kepegawaian Daerah Provinsi Sulawesi Tenggara yang beralamat di Jl. Drs. H. Abdullah Silondae Nomor 114, Kota Kendari merupakan salah satu lembaga teknis daerah sebagai perangkat daerah provinsi sebagaimana dinyatakan dalam Peraturan Daerah (Perda) Provinsi Sulawesi Tenggara Nomor 5 Tahun 2008. Badan Kepegawaian Daerah Provinsi Sulawesi Tenggara mempunyai salah satu fungsi dan tugas yaitu melaksanakan pengolahan data kepegawaian dan didalamnya mempunyai kegiatan yang berkenaan dengan pengelolaan data kepegawaian untuk disajikan dalam bentuk aneka informasi Statistik Pegawai Negeri Sipil dilingkup Pemerintah Provinsi Sulawesi Tenggara.

\section{Hasil dan Analisis Pengukuran Kebisingan}

Berikut ini adalah tabel distribusi frekuensi hasil pengukuran kebisingan pada hari Senin, 27 November 2017 pukul 06.00 - 07.00 WITA.

Tabel 3. Distribusi Frekuensi Pengukuran Kebisingan Senin 27 November 2017 Pukul 06.00 - 07.00 WITA

\begin{tabular}{|c|ccc|c|c|c|}
\hline NO & \multicolumn{2}{|c|}{$\begin{array}{c}\text { INTERVAL } \\
\text { BISING }\end{array}$} & $\begin{array}{c}\text { NILAI } \\
\text { TENGA } \\
\text { H(dB) }\end{array}$ & $\begin{array}{c}\text { FREKUEN } \\
\text { SI }\end{array}$ & $\begin{array}{c}\text { PERSENTAS } \\
\text { E (\%) }\end{array}$ \\
\hline 1 & 49 & - & 53 & 51 & 4 & 3.3 \\
\hline 2 & 54 & - & 58 & 56 & 10 & 8.3 \\
\hline 3 & 59 & - & 63 & 61 & 21 & 17.5 \\
\hline 4 & 64 & - & 68 & 66 & 33 & 27.5 \\
\hline 5 & 69 & - & 73 & 71 & 27 & 22.5 \\
\hline 6 & 74 & - & 78 & 76 & 20 & 16.7 \\
\hline 7 & 79 & - & 83 & 81 & 3 & 2.5 \\
\hline
\end{tabular}




\begin{tabular}{|c|ccc|c|c|c|}
8 & 84 & - & 88 & 86 & 2 & 1.7 \\
\hline 9 & 49 & - & 53 & 51 & 4 & 3.3 \\
\hline \multicolumn{5}{|c|}{ JUMLAH } & 120 & 100 \\
\hline
\end{tabular}

Sumber: Hasil Analisis Data, 2018

Dari tabel distribusi frekuensi diatas kemudian diperoleh histogram histogram hubungan antara tingkat bising dan frekuensi sebagaimana dapat dilihat pada gambar berikut.

\section{Histogram}

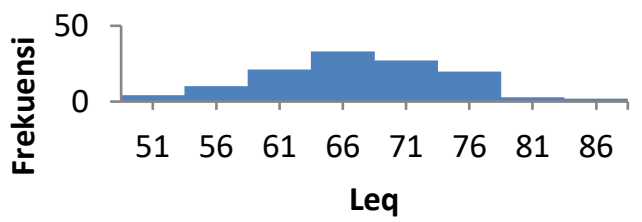

Gambar 5. Histogram Data Kebisingan Senin 27 November 2017 Pukul 06.00-07.00 WITA

Pada gambar 5. luas area dalam histogram adalah:

$\mathrm{A}=i \times(f 1+f 2+f 3+f 4+f 5+f 6+f 7+f 8)$

$\mathrm{A}=5(4+10+21+33+27+20+3+2)=600$

Untuk menghitung L50, dihitung dengan cara sebagai berikut:

$i \times(f 1+f 2+f 3)+f 4 \mathrm{x}=50 \%(\mathrm{~A})$

$5(4+10+21)+33 x=0,5(600)$

$\mathrm{x}=3,8$

$$
33 \mathrm{x}=300-175
$$

Sehingga,

$\mathrm{L} 50=63,5 \mathrm{~dB}+3,8 \mathrm{~dB}=67,3 \mathrm{~dB}$

Untuk menghitung L1, dihitung dengan cara sebagai berikut:

$i \times(f 1+f 2+f 3+f 4+f 5+f 6+f 7)+f 8 \mathrm{y}=99 \%(\mathrm{~A})$

$5(4+10+21+33+27+20+3)+2 \mathrm{y}=0.99(600)$

$2 \mathrm{y}=594-590$

$\mathrm{y}=2$

Sehingga,

$\mathrm{L} 1=83,5 \mathrm{~dB}+2 \mathrm{~dB}=85,5 \mathrm{~dB}$

Untuk menghitung Leq, dihitung dengan cara sebagai berikut:

Leq $=$ L50 $+0.43($ L1-L50)

Leq $=67,3+0,43(85,5-67,3)=75.1 \mathrm{~dB}$

Dengan metode yang sama, maka diperoleh nilai L50, L1 dan Leq untuk setiap waktu pengukuran sebagaimana dapat dilihat pada tabel 4 dan tabel 5

Tabel 4. Fluktuasi Nilai L50, L1, dan Leq Pengukuran Kebisingan Senin, 27 November 2017

\begin{tabular}{|lll|l|l|l|}
\hline \multicolumn{2}{|c|}{ Waktu Pengukuran } & L50 & L1 & $\begin{array}{c}\text { Leq } \\
\text { (L50+0.43x(L1-L50) }\end{array}$ \\
\hline 06.00 & - & 07.00 & 67.3 & 85.5 & 75.1 \\
\hline 07.00 & - & 08.00 & 68.0 & 86.1 & 75.8 \\
\hline 08.00 & - & 09.00 & 69.7 & 88.5 & 77.8 \\
\hline 09.00 & - & 10.00 & 67.2 & 86.3 & 75.4 \\
\hline 10.00 & - & 11.00 & 69.1 & 85.5 & 76.2 \\
\hline 11.00 & - & 12.00 & 66.1 & 84.1 & 73.9 \\
\hline 12.00 & - & 13.00 & 68.6 & 85.7 & 76.0 \\
\hline 13.00 & - & 14.00 & 65.4 & 77.9 & 70.8 \\
\hline 14.00 & - & 15.00 & 66.1 & 84.1 & 73.8 \\
\hline 15.00 & - & 16.00 & 67.1 & 82.2 & 73.6 \\
\hline 16.00 & - & 17.00 & 67.9 & 85.7 & 75.5 \\
\hline 17.00 & - & 18.00 & 70.7 & 84.7 & 76.7 \\
\hline
\end{tabular}

Sumber: Hasil Analisis Data, 2018

Tabel 5. Fluktuasi Nilai L50, L1, dan Leq Pengukuran Kebisingan Kamis, 30 November 2017

\begin{tabular}{|cc|c|c|c|}
\hline \multicolumn{2}{|c|}{ Waktu Pengukuran } & L50 & L1 & $\begin{array}{c}\text { Leq } \\
\text { (L50+0.43x(L1- } \\
\text { L50) }\end{array}$ \\
\hline 06.00 & -07.00 & 61.5 & 77.9 & 68.6 \\
\hline $07.00-$ & 08.00 & 62.8 & 76.7 & 68.8 \\
\hline $08.00-$ & 09.00 & 64.3 & 74.7 & 68.8 \\
\hline $9.00-10.00$ & 64.4 & 82.1 & 72.0 \\
\hline $10.00-11.00$ & 64.6 & 79.7 & 71.1 \\
\hline $11.00-12.00$ & 53.4 & 77.7 & 63.9 \\
\hline $12.00-13.00$ & 64.3 & 77.2 & 69.8 \\
\hline $13.00-14.00$ & 66.5 & 88.1 & 75.8 \\
\hline
\end{tabular}




\begin{tabular}{|lll|l|l|l|}
14.00 & - & 15.00 & 65.2 & 85.5 & 73.9 \\
\hline 15.00 & -16.00 & 65.3 & 75.6 & 69.7 \\
\hline $16.00-17.00$ & 65.1 & 77.8 & 70.6 \\
\hline $17.00-18.00$ & 66.1 & 83.7 & 73.7 \\
\hline
\end{tabular}

Sumber: Hasil Analisis Data, 2018

Kondisi pengukuran kebisingan pada Jalan Drs. H. Abdullah Silondae selama penelitian berlangsung berjalan normal, tidak adanya gangguan yang dapat menambah nilai tingkat kebisingan yang ditangkap oleh Sound Level Meter (SLM). Cuaca pada saat pengukuran dalam keadaan cerah. Jalan Drs. H. Abdullah Silondae melintasi kawasan perkantoran, dimana batas nilai tingkat kebisingan berdasarkan Kepmen LH No. 48 Tahun 1996 adalah $65 \mathrm{~dB}$. Berikut adalah grafik tingkat kebisingan untuk Jalan Drs. H. Abdullah Silondae pada Senin dan Kamis sebagaimana dapat dilihat pada Gambar 6.

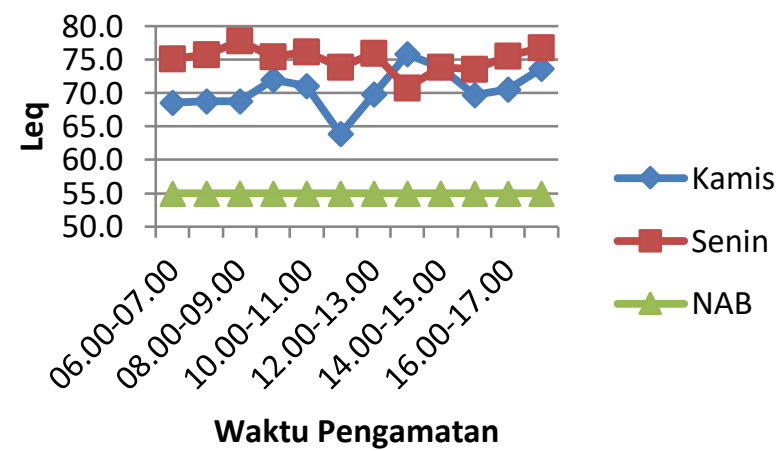

\section{Gambar 6. Tingkat Kebisingan Terhadap Nilai Ambang Batas}

Berdasarkan gambar 4.2 terlihat bahwa nilai Leq untuk seluruh waktu pengamatan telah melewati nilai ambang batas kebisingan untuk kawasan perkantoran yaitu $65 \mathrm{~dB}$ dengan nilai Leq tertinggi $77.7 \mathrm{~dB}$ dan nilai Leq terendah sebesar $63.9 \mathrm{~dB}$ dengan rata-rata nilai Leq selama 2 hari sebesar $72.8 \mathrm{~dB}$.

\section{Prediksi Kebisingan}

Tingkat kebisingan ekuivalen rata-rata selama 2 hari adalah $72,8 \mathrm{~dB}$ yang diukur pada jarak 1,6 $\mathrm{m}$ dari pinggir perkerasan jalan. Adapun prediksi tingkat kebisingan pada ruangan kantor menggunakan persamaan sebagai berikut :

$$
\begin{array}{ll}
\mathrm{L} 2 & =\mathrm{L} 1-10 \log (\mathrm{r} 2 / \mathrm{r} 1) \mathrm{dBA} \\
\operatorname{Leq}(18 \mathrm{~m}) & =72,8-10 \log (18 / 1,6)
\end{array}
$$

$$
=62,2 \mathrm{dBA}
$$

Tabel 6. Prediksi Kebisingan Pada Ruangan Kantor

\begin{tabular}{|c|l|c|c|}
\hline NO & \multicolumn{1}{|c|}{ RUANGAN } & $\begin{array}{c}\text { JARAK DARI } \\
\text { SUMBER BISING }\end{array}$ & $\begin{array}{c}\text { PREDIKSI } \\
\text { KEBISINGAN }\end{array}$ \\
\hline 1 & KASUBAG KEUANGAN & 25.7 & 60.64 \\
\hline 2 & KASUBAG UMUM \& KEPEGAWAIAN & 29.6 & 60.03 \\
\hline 3 & KASUBID MUTASI PEGAWAI & 33.5 & 59.49 \\
\hline 4 & KASUBID MUTASI JABATAN FUNGSIONAL & 33.5 & 59.49 \\
\hline 5 & KASUBID PEMBERDAYAAN PEGAWAI & 33.5 & 59.49 \\
\hline 6 & KASUBID KESEJAHTERAAN & 33.5 & 59.49 \\
\hline 7 & KASUBID PENSIUN & 18 & 62.19 \\
\hline 8 & KASUBID PENGEMBANGAN & 33.5 & 59.49 \\
\hline 9 & SEKRETARIS BKD & 18 & 62.19 \\
\hline 10 & KABID DISIPLIN KES \& PENSIUN & 25.7 & 60.64 \\
\hline 11 & KASUBID MUTASI JABATAN STRUKTURAL & 33.5 & 59.49 \\
\hline 12 & KABID PENGADAAN \& MUTASI & 33.5 & 59.49 \\
\hline 13 & KASUBIG INFORMASI & 40.9 & 58.62 \\
\hline 14 & KASUBID DOKUMENTASI & 40.9 & 58.62 \\
\hline 15 & KASUBID PENGOLAHAN DATA & 38.5 & 58.89 \\
\hline
\end{tabular}

Sumber : Hasil Analisis Data, 2018

\section{Karakteristik Responden}

a) Jenis Kelamin

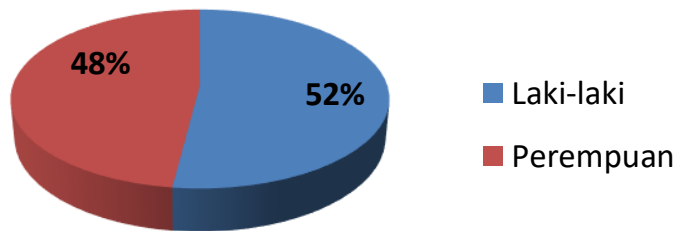

Gambar 7. Karakteristik Responden Berdasarkan Jenis Kelamin

Gambar 7 menunjukkan bahwa responden terdiri dari $52 \%$ laki-laki dan $48 \%$ perempuan.

b) Karakterisitik Berdasarkan Usia

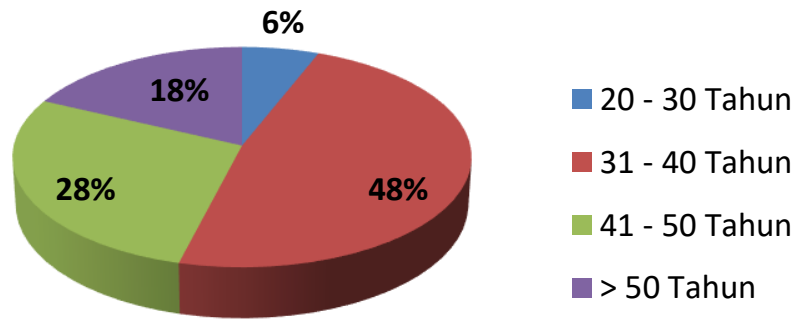

Gambar 8. Karakteristik Responden Berdasarkan Tingkat Usia

Gambar 8. menunjukkan bahwa responden dengan rentang usia $20-30$ tahun sebanyak $6 \%$, 
31 - 40 tahun sebanyak 48\%, 41-50 tahun sebanyak $28 \%$ responden dan di atas 50 tahun sebanyak $18 \%$

c) Status Kepegawaian

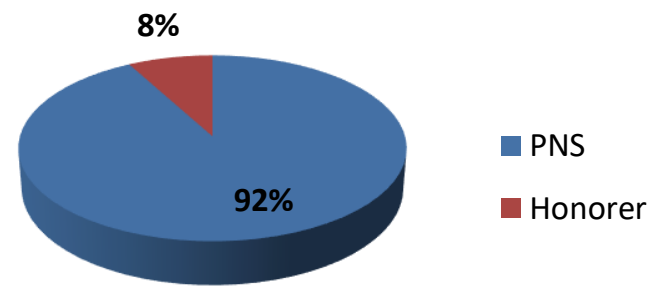

Gambar 9. Karakteristik Responden Berdasarkan Status Kepegawaian

Gambar 9. menunjukkan bahwa responden yang bekerja sebagai PNS sebanyak $92 \% \%$, dan honorer sebanyak $8 \%$.

d) Tingkat Pendidikan

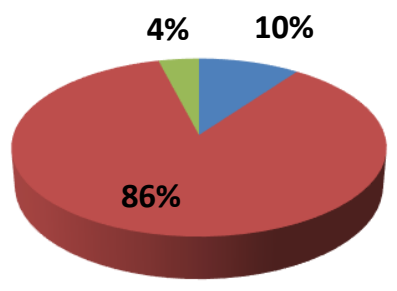

SMA/Sederajat
Diploma /
Sarjana
Pasca Sarjana \&
S3

Gambar 10. Karakteristik Responden Berdasarkan Tingkat Pendidikan

Gambar 10 menunjukkan bahwa responden dengan tingkat pendidikan terakhir SMA/sederajat sebanyak $10 \%$ responden, diploma/sarjana sebanyak $86 \%$, dan pasca sarjana \& S3 sebanyak 4\%.

e) Tingkat pendapatan Perbulan

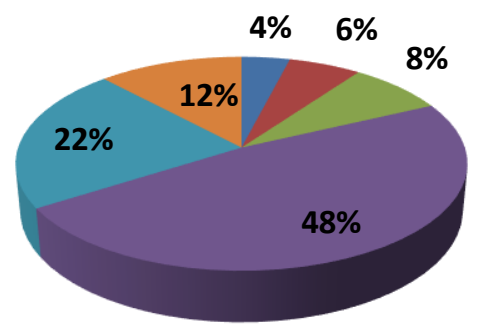

घ<Rp. 1.000 .000

Rp. 1.000 .000 -

Rp. 2.000 .000

Rp.2.000.000 Rp. 3.000 .000

Rp. 3.000 .000 -

Rp. 4.000 .000

Gambar 11. Karakteristik Responden Berdasarkan Tingkat Pendapatan

Gambar 11. menunjukkan bahwa responden dengan tingkat pendapatan $<1.000 .000$ sebanyak
$4 \%, \quad 1.000 .000-2.000 .000$ sebanyak 6\%, $2.000 .000-3.000 .000$ sebanyak $8 \%, 3.000 .000$ - 4.000.000 sebanyak 48\%, 4.000.000 5.000 .000 sebanyak $22 \%$, dan $>5.000 .000$ sebanyak $12 \%$,

f) Masa Kerja

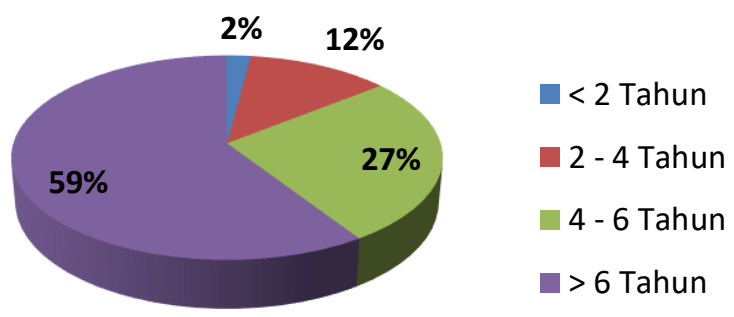

Gambar 12. Karakteristik Responden Berdasarkan Masa Kerja

Gambar 12 menunjukkan bahwa responden berdasarkan masa kerja $<2$ tahun sebanyak $2 \%$, $2-4$ tahun sebanyak $12 \%, 4-6$ tahun sebanyak $27 \%$, dan $>6$ tahun sebanyak $59 \%$.

\section{Karakteristik Ketergangguan Individu}

a) Kondisi Tingkat Kebisingan

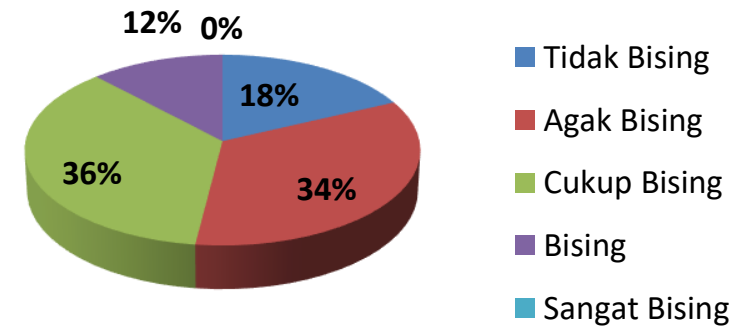

Gambar 13. Persepsi Ketergangguan Individu Berdasarkan Kondisi Tingkat Kebisingan

Gambar 13. menunjukkan bahwa $18 \%$ responden yang menyatakan di kawasan tersebut tidak bising, 34\% menyatakan agak bising, 36\% menyatakan cukup bising, $12 \%$ menyatakan bising, dan $0 \%$ menyatakan sangat bising.

b) Kondisi Tingkat Ketergangguan

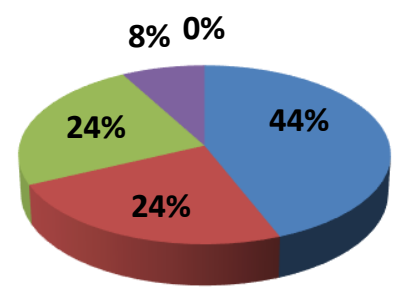

- Tidak Terganggu

Agak Terganggu

Cukup

Terganggu

- Terganggu 
Gambar 14. Persepsi Ketergangguan Individu Akibat Kebisingan

Gambar 14. menunjukkan bahwa $44 \%$ responden yang menyatakan tidak terganggu dengan kebisingan di kawasan tersebut, 24\% responden yang menyatakan agak terganggu, $24 \%$ menyatakan cukup terganggu, dan $8 \%$ menyatakan terganggu

c) Keinginan Untuk Pindah

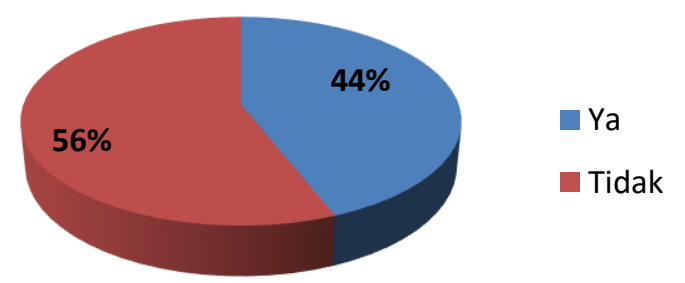

Gambar 15. Persepsi Ketergangguan Individu Berdasarkan Keinginan Untuk Pindah

Gambar 15. menunjukkan bahwa 56\% responden menyatakan tidak ingin pindah ke tempat yang lebih tenang dan $44 \%$ responden menyatakan ingin pindah ke tempat yang lebih tenang.

d) Jenis Penanganan

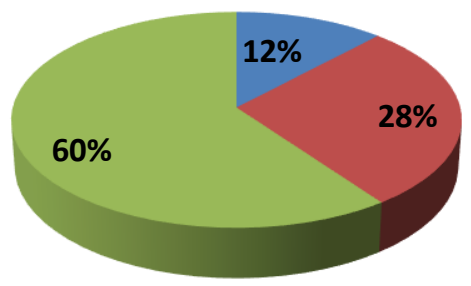

\footnotetext{
Penetapan jarak sempadan

- Rekayasa lalu lintas

- Pemindahan lokasi
}

Gambar 16. Persepsi Ketergangguan Individu Berdasarkan Jenis Penanganan

Gambar 16. menunjukkan bahwa 12\% responden mengusulkan penetapan jarak sempadan, $28 \%$ responden mengusulkan rekayasa lalu lintas, $60 \%$ responden mengusulkan pemindahan lokasi sebagai solusi mengurangi kebisingan di kawasan tersebut.

\section{Uji Chi Square}

Berikut ini ditampilkan hasil analisis chi square antara karakteristik responden dan tingkat ketergangguan

Tabel 7. Hasil Uji Chi Square

\begin{tabular}{|l|l|}
\hline & Asymp. Sig. \\
\hline $\mathrm{X} 1 * \mathrm{Y}$ & 0.182 \\
\hline $\mathrm{X} 2 * \mathrm{Y}$ & 0.677 \\
\hline $\mathrm{X} 3 * \mathrm{Y}$ & 0.241 \\
\hline $\mathrm{X} 4 * \mathrm{Y}$ & 0.163 \\
\hline $\mathrm{X} 5 * \mathrm{Y}$ & 0.494 \\
\hline $\mathrm{X} 6 * \mathrm{Y}$ & 0.264 \\
\hline
\end{tabular}

Sumber: Hasil Analisis Data, 2018

Untuk mengetahui hubungan antara karakteristik responden dengan tingkat ketergangguan digunakan taraf signifikan yaitu $\alpha(0,05)$ :

a) Apabila $\mathrm{p}<0,05=$ Ho ditolak, berarti ada hubungan antara karakteristik responden dengan tingkat ketergangguan.

b) Apabila $p>0,05=$ Ho diterima, berarti tidak ada hubungan antara karakteristik responden dengan tingkat ketergangguan.

Berdasarkan tabel 7. diketahui bahwa seluruh karakteristik responden memiliki nilai $p$ (Asymp. Sig.) > 0.05 yang berarti tidak ada hubungan antara karakteristik responden dengan tingkat ketergangguan.

\section{Pengaruh Tingkat Ketergangguan Terhadap Kebisingan}

Untuk mengetahui hubungan antara tingkat kebisingan dan tingkat ketergangguan maupun dengan variabel-variabel lainnya menggunakan korelasi Spearman Rank sebagaimana dapat dilihat pada tabel 8 .

Tabel 8. Korelasi Spearman Rank

\begin{tabular}{|c|c|c|c|c|c|c|c|c|}
\hline & & LEQ & $\mathrm{X} 1$ & $x 2$ & $\times 3$ & X4 & X5 & $x 6$ \\
\hline \multirow[t]{3}{*}{$\begin{array}{l}\text { Spearman Y } \\
\text { Rank }\end{array}$} & $\begin{array}{l}\text { Koefisien } \\
\text { Korelasi }\end{array}$ & 0.796 & 0.175 & & 0.183 & $0.332^{*}$ & 0.163 & 0.259 \\
\hline & $\begin{array}{l}\text { Sig. (2- } \\
\text { tailed) }\end{array}$ & 0.000 & 0.301 & 0.305 & 0.278 & 0.045 & 0.334 & 0.121 \\
\hline & $\mathrm{N}$ & 37 & 37 & 37 & 37 & 37 & 37 & 37 \\
\hline
\end{tabular}

the 0.01 level (2-tailed).

Sumber: Hasil Analisis Data, 2018

Tabel 8. menunjukkan bahwa tingkat kebisingan (LEQ) mempunyai korelasi positif 
yang kuat terhadap tingkat ketergangguan (Y) sebesar 0.796 pada tingkat kepercayaan $99 \%$. Sedangkan variabel jenis kelamin (X1), usia (X2), tingkat pendidikan terakhir (X3), tingkat pendapatan perbulan (X4), masa kerja (X5), dan status kepegawaian (X6) memiliki korelasi yang sangat rendah terhadap tingkat ketergangguan. Menurut Bangun, Kamil, dan Putra (2009) Dasar pengambilan keputusan yang digunakan dengan berdasarkan probabilitas. Jika probabilitas > 0.025 , maka H0 diterima, Jika probabilitas < 0.025, maka H0 ditolak. Dapat dilihat pada kolom Sig/significance pada Tabel 8. antara tingkat kebisingan (Leq) dan tingkat ketergangguan individu adalah 0.000 atau probabilitas < 0.025. Maka H0 ditolak yang berarti tingkat kebisingan memiliki pengaruh yang signifikan terhadap tingkat ketergangguan pegawai.

Selanjutnya dilakukan analisis regresi untuk memprediksi tingkat ketergangguan pegawai sebagaimana dapat dilihat pada gambar 17 .

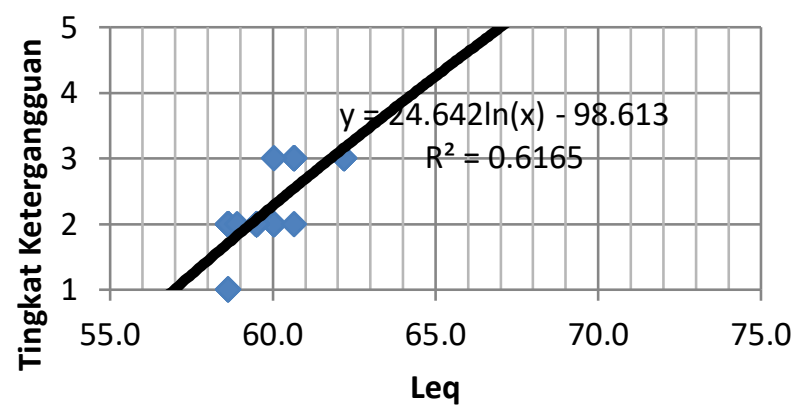

Gambar 17. Hasil Analisis Regresi

Berdasarkan hasil analisis regresi dengan tingkat kebisingan sebagai variabel bebas (x) dan tingkat ketergangguan sebagai variabel terikat (y), model regresinya adalah: $\mathrm{Y}=24.642$ $\ln (\mathrm{X})$ - 98.613 dengan nilai $\mathrm{R}^{2}=0.6165$. Dari gambar 17. diketahui batas tingkat kebisingan di tiap skala ketergangguan berdasarkan perpotongan garis trendline dengan garis skala ketergangguan adalah sebagai berikut:

$$
5=\text { Sangat Terganggu }
$$

\section{KESIMPULAN}

1. Tingkat kebisingan rata-rata di Jalan Drs. H. Abdullah Silondae mencapai 72,8 dB. Tingkat kebisingan tersebut telah melewati standar baku mutu kebisingan untuk kawasan perkantoran yaitu sebesar $65 \mathrm{~dB}$.

2. Persepsi pegawai BKD akibat gangguan kebisingan di Jalan Drs. H. Abdullah Silondae adalah $44 \%$ responden yang menyatakan tidak terganggu, $24 \%$ responden yang menyatakan agak terganggu, 24\% menyatakan cukup terganggu, dan $8 \%$ menyatakan terganggu.

3. Kebisingan memiliki pengaruh yang signifikan terhadap tingkat ketergangguan pegawai BKD.

\section{SARAN}

1. Hasil tingkat kebisingan yang diperoleh dari penelitian ini melebihi standar baku sehingga perlu di lakukan penanganan untuk dapat mereduksi tingkat kebisingan.

2. Di sarankan kepada peneliti selanjutnya untuk mengkaji hubungan ketergangguan pegawai akibat getaran kendaraan yang melintas di jalan raya.

3. Untuk penelitian selanjutnya, data ketergangguan perlu transformasikan dari data ordinal menjadi data interval menggunakan metode suksesi interval.

Tabel 9. Skala Tingkat Ketergangguan

\begin{tabular}{|l|l|l|l|l|l|}
\hline $\begin{array}{l}\text { Tingkat } \\
\text { Ketergangguan }\end{array}$ & 1 & 2 & 3 & 4 & 5 \\
\hline Leq $(\mathrm{dB})$ & 57 & 59,5 & 62 & 64,5 & 67 \\
\hline
\end{tabular}

Sumber: Hasil Analisis Data, 2018

Ket: $\quad 1=$ Tidak Terganggu

$2=$ Agak Terganggu

$3=$ Cukup Terganggu

$4=$ Terganggu 


\section{DAFTAR PUSTAKA}

Anonim. 1996. Keputusan Menteri Negara Lingkungan Hidup No. 48 Tahun 1996 tentang Baku Mutu Kebisingan.

Anonim. 1999. Keputusan Menteri Tenaga Kerja Nomor 51 Tahun 1999 tentang Nilai Ambang Batas Faktor Fisika di Tempat Kerja.

Banerjee, D., S.K Chakraborty, S. Bhattacharyya, dan A. Gangopadhyay. 2008. Attidunal Response Towards Road Traffic Noise in The Industrial Town of Asansol, India. Environment Monitoring Assesment 151 (2009) : 3744

Bluhm, G., Nordling, E., dan Berglind, N. 2004. Road traffic Noise and Annoyance - An Increasing Environmental Health Problem. Noise and Health 6:24, page 43-49.

Lakawa, I., Lawalenna Samang., Mary Selintung., Muralia Hustim. (2016). Noise Level Study Based On Traffic Characteristics, Physical, and Environmental Aspects of Road. International Journal of Civil Engineering and Technology (IJCIET), Vol. 7(1), pp; 188-198. ISSN 09766316, http://www.iaeme.com.ijciet/ index.asp.

Leonard. 2014. Analisis Tingkat Kekuatan Bunyi Klakson Kendaraan Ringan di Kota Makassar. Makassar: Fakultas Teknik Universitas Hasanuddin.

Li,H., Yu, W., Lu, J., dan Zhao, Y. 2008. Investigation of Road-Traffic Noise and Annoyance in Beijing : A Cross-Sectional Study of 4th Ring Road. ProQuest Biology Journals, Vol 63, pages 27.

Maulidya, T. 2011. Hubungan Karakteristik Dengan Tingkat Pengetahuan Ibu Bayi Usia9-12 Bulan Tentang Pemberian Imunisasi Dasar Di Wilayah Kerja Puskesmas Guntur II Demak Tahun 2011. Semarang : Universitas Muhammadiyah Semarang.

Martono, H. Sukar, N. Sulistiyani. 2008. Tingkat Kebisingan di DKI Jakarta dan sekitarnya,

http://www.litbang.depises.go.id, 07042010.

Setiawan R. 2001 "Analisa Tingkat Kebisingan Lalu Lintas Pada Jalan Tol Ruas Waru Sidoarjo". Available from: http://fportfolio.petra.ac.id, October 2 2008.

Suciptawati, N. P. 2010. Metode Statistika Nonparametrik. Denpasar: Udayana University Press

Sufren dan Natanael, Y. 2013. Mahir Menggunakan SPSS Secara Otodidak. Jakarta: PT. Elex Media Komputindo

Sugiyono.(2010). Metode Penelitian Kuantitatif Kualitatif \& RND, Alfabeta, Bandung.

Wardika, I Ketut, I Gusti Putu Suparsa dan D.M. 2012. Analisis Kebisingan Lalu Lintas pada Ruas Jalan Arteri. Denpasar: Fakultas Teknik Universitas Udayana. 
